\title{
Curcumin promotes cholesterol efflux from brain through LXR/RXR-ABCA1-apoA1 pathway in chronic cerebral hypoperfusion aging-rats
}

\author{
Mingyuan Tian 1,2,3, Linhui Wang ${ }^{1,2,3}$, Gang Yu ${ }^{4}$, Bin Liu ${ }^{1,2,3}$, Yu Li $i^{1,2,3^{*}}$ \\ From 2011 International Conference on Molecular Neurodegeneration \\ Shanghai, China. 22-24 September 2011
}

\section{Background}

Chronic cerebral hypoperfusion has been well depicted as a common pathological status contributing to neurodegenerative disease such as vascular dementia $(\mathrm{VaD})$ and Alzheimer's dementia (AD). Cholesterol is critical to brain growth, but high levels of cholesterol have been associated with neurogenerative disease. The liver $\mathrm{X}$ receptor- $\beta /$ retinoid $X$ receptor $-\alpha$ (LXR/RXR)-regulated gene ABCA1 effluxes cellular cholesterol to apolipoprotein A1 (apoA1), which play important role in reverse cholesterol transport. Recent studies have found that Curcumin decrease brain inflammation and exert neuroprotective effect. We hypothesized that Curcumin may alleviate hypoperfusion through affecting cholesterol homeostasis by LXR/RXR-ABCA1-apoA1 pathway.

\section{Method}

Male Sprague-Dawley rats were subjected to permanent occlusion of bilateral common carotid arteries $(2 \mathrm{VO})$ to produce chronic cerebral hypoperfusion. Animals were randomly divided into 5 groups: normal control group, sham-operated group, $2 \mathrm{VO}$ group, $2 \mathrm{VO}+\mathrm{Curcu}-$ $\mathrm{min} 100 \mathrm{mg} / \mathrm{kg}$ group, $2 \mathrm{VO}+$ Curcumin $50 \mathrm{mg} / \mathrm{kg}$ group. Low doses of Curcumin $(50 \mathrm{mg} / \mathrm{kg})$ or high doses of Curcumin $(100 \mathrm{mg} / \mathrm{kg})$ were dissolved in DMSO. All animals were injected intraperitoneally with DMSO solution of Curcumin or a same volume of normal DMSO after surgery. Each group was injected once daily for four consecutive weeks. The spatial learning capacity and cognitive function of these animals was assessed in the Morris water maze 30 days after the onset of $2 \mathrm{VO}$. The expressions of LXR/RXR, ABCA1 and apoA1 in

1Department of Pathology, Chongqing Medical University, Chongqing 400016, China

Full list of author information is available at the end of the article hippocampus were detected by western blot and immunohistochemistry.

\section{Result}

Spatial learning in the Morris water maze was significantly improved by the treatment of Curcumin comparing to 2 VO group $(\mathrm{p}<0.05)$. Meanwhile, LXR- $\beta / R X R-\alpha$, $A B C A 1$ and apoA1 protein levels were increased in $2 \mathrm{VO}+\mathrm{Curcumin}$ group $(\mathrm{p}<0.05)$. Interestingly, $2 \mathrm{VO}$ + Curcumin group had higher serum HDL cholesterol levels and total cholesterol (TC) levels than that of $2 \mathrm{VO}$ group $(\mathrm{p}<0.05)$. However, there were no statistical differences among $2 \mathrm{VO}+\mathrm{Curcumin}$ group rats, sham-operated group rats and normal control group rats $(\mathrm{p}>0.05)$.

\section{Conclusion}

We suggest that Curcumin have a protective influence on spatial learning in $2 \mathrm{VO}$ group rats. We also suppose that Curcumin may act a role of LXR agonist and then activate the ABCA1 promoter and increase ABCA1 protein levels and apoA1 dependent cellular cholesterol efflux from brain. This is the first study to show that Curcumin can alleviate hypoperfusion by LXR/RXRABCA1-apoA1 pathway.

\section{Acknowledgement}

This study was supported by Program for Excellent talent in University of Chongqing (2010)

\section{Author details}

'Department of Pathology, Chongqing Medical University, Chongqing 400016, China. ${ }^{2}$ Institute of Neuroscience, Chongqing Medical University, Chongqing 400016, China. ${ }^{3}$ Chongqing Key Laboratory of Neurobiology, Chongqing Medical University, Chongqing 400016, China. ${ }^{4}$ Department of Neurology, The First Affiliated Hospital, Chongqing Medical University, Chongqing 400016, China. 
Submit your next manuscript to BioMed Central and take full advantage of:

- Convenient online submission

- Thorough peer review

- No space constraints or color figure charges

- Immediate publication on acceptance

- Inclusion in PubMed, CAS, Scopus and Google Scholar

- Research which is freely available for redistribution

Submit your manuscript at www.biomedcentral.com/submit
C) Biomed Central 